\title{
Some Key Evolutionary Changes In Global Economic Development: A Historical Perspective
}

Alex J. Kondonassis, University of Oklahoma, USA

\begin{abstract}
Our knowledge regarding global economic development has increased as a result of three major changes: Changes in measuring economic development and particularly the introduction of the U.N. human development index; The recognition that non-economic or institutional factors are important in explaining development; the awareness that policy making has experienced "swing of the pendulum" whereby a policy position is followed by another with the end result a compromise or eclecticism.
\end{abstract}

Keywords: economic development; economic history

\section{INTRODUCTION}

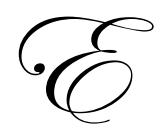

conomics like any other science has evolved over time so that it appears that we have come closer to the truth. Economic development as part of the broader discipline of economic science has also experienced several evolutionary changes. Many of these changes have taken place particularly after the end of World War II when intense interest in the study of economic development has occurred. Some of these changes relate to the measurement of economic development, others pertain to the theoretical explanations of economic development and still others are policy oriented.

\section{CHANGES IN MEASURING DEVELOPMENT}

The term of economic development has become differentiated from the term economic growth. While economic growth refers to an increase in income and production economic development has acquired a broader meaning including structural changes leading to multifaceted improvements on the fight against poverty in the less developed countries (LDCs).

Early post War World II efforts to measure economic development focused on using per capita income. It was favored as compared to aggregate yardsticks, e.g., gross domestic product or national income, largely because it took under account population growth. A major weakness is that it is an average and does not address the question of distribution of income or wealth. Another development came from the recognition that the cost of a given basket of goods is lower in the less developed countries than in the developed countries. This led to using international dollars or purchasing power parity dollars as a more accurate means of making comparisons of standards of living.

The United Nations recently has introduced a new more comprehensive yardstick, the human development index. This index is defined as one measuring achievement in three basic dimensions of human development: health, knowledge and standard of living. Health is measured by life expectancy at birth; knowledge is measured by adult literacy and combines gross enrolment in primary, secondary and tertiary level education and standard of living is measured by gross domestic product per capita in purchasing power parity U.S. dollars. Table 1 shows a large difference in the human development index of the Sub-Sahara Africa countries and the OECD countries (developed countries). Notwithstanding that many of the less developed countries are non- monetized and the accuracy of their data is questionable, it can be argued that considerable progress has been made in assessing their development as suggested by the above changes. 


\section{THE IMPORTANCE OF INSTITUTIONS}

In the area of theoretical explanations of development we have experienced several new ways of looking at things. To the classical production function, $0=\mathrm{f}(\mathrm{L}, \mathrm{La}, \mathrm{C}, \mathrm{T}$ ) (Output is a function of land, labor, capital and technology) we find Schumpeter (1961) stressing the importance of the entrepreneur who is a function of profit (R) and the socio-political environment $(\mathrm{x}),(\mathrm{f}=\mathrm{f}(\mathrm{x}, \mathrm{R})$. In addition to Schumpeter's emphasis on non-economic influence we see other writers focusing on the importance of non-economic or institutional factors as explanations to development. For instance Max Weber (1930) makes a great deal of the rise of the Protestant Ethic as a major contributor to the development of Western Europe and W.W. Rostow (1961) in his Stages of Economic Growth argues that his key stage the "Take-off" depends among other things on political stability. Similarly McClelland (1962) proposes that entrepreneurial activity is influenced by religion, education and the family while Hagen (1962) suggests that economic development can only be explained by integrating lessons from anthropology, sociology and psychology. Finally Boeke (1953) who introduced the phenomenon of social dualism feels what explains differences in standards of living is disparities in social values among countries. He further suggests that theories of the West are of little relevance to the less developed countries. Thus, it appears that development economists must be persuaded to give non-economic or institutional factors an important place in explaining the process of economic development. The diagram below represents an attempt to combine the major economic factors with the institutional component of development.

Table 1: Human Development Index

\begin{tabular}{|l|c|c|c|c|}
\hline & $\begin{array}{c}\text { Human Development } \\
\text { Index }\end{array}$ & $\begin{array}{c}\text { Life Expectancy at } \\
\text { Birth (Years) }\end{array}$ & $\begin{array}{c}\text { Adult Literacy Rate } \\
\text { \% Aged 15 and } \\
\text { Above }\end{array}$ & $\begin{array}{c}\text { GDP per Capita U.S. } \\
\text { Dollars }\end{array}$ \\
\hline & $\mathbf{2 0 0 5}$ & $\mathbf{2 0 0 5}$ & $\mathbf{1 9 9 5 - 2 0 0 5}$ & $\mathbf{2 0 0 5}$ \\
\hline Developing Countries & 0.691 & 66.1 & 76.7 & 5282 \\
\hline $\begin{array}{l}\text { Least Developed } \\
\text { Countries }\end{array}$ & 0.488 & 54.5 & 53.9 & 1499 \\
\hline Arab States & 0.699 & 67.5 & 70.3 & 6716 \\
\hline East Asia and Pacific & 0.771 & 71.7 & 90.7 & 6604 \\
\hline South Asia & 0.611 & 63.8 & 59.5 & 3416 \\
\hline Sub-Sahara Africa & 0.493 & 49.6 & 60.3 & 1998 \\
\hline OECD Countries & 0.947 & 79.3 & & 29197 \\
\hline
\end{tabular}

Source: Human Development Report 2007/2008, United Nations Development Programme, New York, New York.

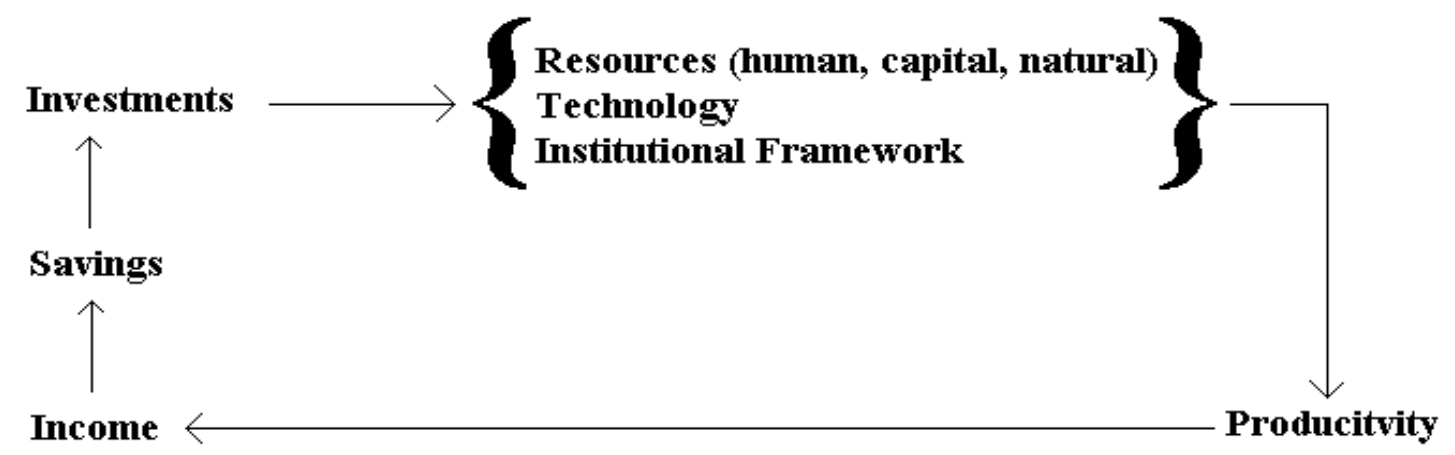

\section{POLICY SWINGS OF THE PENDULUM}

Concerning policy making it is interesting to note that it has been characterized by what may be called "swings of the pendulum." One policy position has been succeeded by another with an eventual synthesis or an eclectic approach. 
Right after the end of World War II in their effort to combat poverty the LDCs were faced with a dilemma of choosing a development strategy, as Jan Tinbergen puts it (1967), from the doctor of the East, the Soviet Union, or from the doctor of the West, the U.S.A. Several LDCs engaged in a strategy of comprehensive economic planning which seemed to give them a measure of fascination for a quick fix. Yet unreliable data, inadequate resources and political instability often rendered the results of their planning disappointing. Thus, we have seen in recent years a swing of the pendulum to smaller scale planning e.g., projects planning and privatization. Experiences suggest that a compromise approach has emerged for combining the advantages of the market wherever it works with the interventionist role of the government in providing monetary stability, building the infrastructure and promoting education, health and other externalities. The cases of Japan, South Korea, Taiwan, India and more recently China illustrate the use of the eclectic approach in development. Guided capitalism leading to market orientation has characterized the cases of Japan, South Korea and Taiwan while centralized economic planning and socialism have been succeeded by liberalization and market socialism in India and China.

No matter whether planning or the market are chosen as the preferred strategy for development all LDCs have to decide on the role that agriculture or industry would play in their development efforts. More than half of the population of the poorest LDCs live in low productivity agriculture. Getting away from this situation may explain the post World War II lack of attention on agriculture and the focus on industrial development. Economists like Raul Prebish (1862) and Hans Singer (1950) strongly argued in favor of protectionism and industrialization via import substitution. Industrial development was expected to break up the traditional character of the LDCs and provide large spread effects. Yet experiences with import substitution have not been uniformly positive on economic development. A major lesson learned was that the production of non-consumer goods depended on a sizeable market, adequate technology, managerial talents and capital subsidization of imported capital goods by governments.

An alternative strategy for industrialization was tried via export orientation. It was attempted mostly in the 1980s and 1990s. It required resource reallocations, technological changes and improvements in efficiencies. Economies which have used this strategy successfully include South Korea, Singapore, Hong Kong, Taiwan and China.

A major advantage of this approach is to provide a larger market for small countries. Many of the LDCs, especially the small ones, realized that industrialization was not attainable by individual countries acting alone. Cooperation and possibly integration with other countries emerged as a possible avenue to be followed. To date several experiments with integration have been initiated with different degrees of success, e.g., NAFTA, Andean Group, the East African Development Community, Mercosur. Economic theorists argue that LDCs of the same size and of similar stage of development may benefit from economic integration. However, experiences show that for these benefits to accrue, putting aside nationalistic interests and developing attitudes of compromise and give and take are necessary. Otherwise conflicts will arise as the cases of the Central American Common Market and the East African Community illustrate.

While a number of countries experimented with import substitution or export expansion and integration they have come to realize lately that neglect of agriculture was a serious error. Given the fact that most people in the LDCs live on the land, the contributions that agriculture can make toward development has acquired central importance in recent years. It is generally recognized now that a high productivity agriculture can provide labor to the industrializing sector. Providing adequate amounts of food to feed the people of the country is certainly a major accomplishment of high productivity agriculture. But for these happenings to take place, the prevailing subsistence agriculture has to be changed with emphasis on reforms and a movement toward optimum size farms as well as using tested approaches to cultivating the land including fertilization, irrigation and crop rotation. It can be argued that another "swing of the pendulum" has taken place from industrialization to agriculture. Emphasis on one strategy or another and/or possibly a combination of the two depends on the particular country's circumstances. Awareness of all the options and the experiences of their respective advantages and disadvantages is instructive and useful. Pragmatic and eclectic policies may be in order.

Immediately after World War II presumably because of the preeminent role assigned to physical capital formation by the classical and neoclassical theories and reinforced by economists such as Schumpeter, Rostow and 
others, physical capital formation was viewed as necessary and perhaps sufficient condition for economic development. For instance Benjamin Higgins (1968) argues that capital formation is the very core of economic development. On the other hand, other economic experts stress the importance of human capital if physical capital is to be used effectively. The key to development is man and that his abilities, values and attitudes must be changed in order to accelerate the process of development (Meier, 1976). Nobel winner Simon Kuznets (1955) argues that the major stock of an economically advanced country is not its physical capital but the body of knowledge of the population which can use physical capital effectively. So it appears that physical capital and human capital are viewed as complementary and an increase in the stock of physical capital necessitates an improvement in the quality of human capital in order for the rate of absorptive capacity to keep pace with the rate of technological advancement.

Intrinsic to the formation and maintenance of human capital is education. Education enables countries to benefit from technological innovation; a highly educated labor force is a prerequisite to the attainment of full human development. To this end scholars such as Schultz (1961), Bowman (1966), Lewis (1966) and Mincer (1958), to mention a few, have all discussed the priority that must be placed in the investment of human capital in order to have a systematic and sustained increase in economic development. A critical issue is how to use education in order to improve the quality of stock of human capital. It is generally known education is multidimensional, it is complex and is expensive. Yet it can have multifaceted impacts. Among them, it helps improve skills, influences changes in ideas and values, contributes toward entrepreneurship and helps raise productivity and income. Concerning its multidimensional nature it has been recognized that primary, secondary, college and vocational tech education are all important in raising the level of education in a given country. Because it is expensive it becomes necessary for a country with limited resources to prioritize where to focus its attention or where it will do the most good. In the 1960s secondary and college education seemed to be favored. With regard to college education many LDCs experienced a brain drain. Encouraging students to specialize in programs relevant to the home country and providing financial assistance to students staying at home may help reduce the brain drain problem. In recent years, the emphasis seems to have shifted to primary education. G. Psacharopoulos and M. Woodhall (1985) have stressed that investments in education provided higher returns than returns from investment in physical capital and that investment in primary education showed higher returns than investments in general education.

Health and nutrition also affect productivity and development. Development in turn affects health and poor nutrition unfavorably affects energy and ability to work. Recognition of these relationships led the U.N. to develop the human development index, which is based on life expectancy, literacy and per capita income, a reflection of health, education and income. The above discussion suggests that we may have another swing of the pendulum from emphasis of physical capital to human capital and yet the importance of both leads to an eclectic approach.

\section{CONCLUSIONS}

We have shown that improvements have taken place in measuring economic development particularly with the introduction and use of the U.N. human development index. In the area of theory we have noted that several theorists have stressed the importance of non-economic or institutional factors in explaining global economic development, e.g. political stability, religion, education, social values. In policy making, e.g. economic planning versus the market, industrial development versus agricultural development, physical capital versus human capital formation, have illustrated that so called "swings of the pendulum" have taken place from one policy position to another with eclecticism the final result.

As a result of these changes it is warranted to conclude that our knowledge of the process of global economic development has improved substantially and so has the practice of development economics.

\section{AUTHOR INFORMATION}

Alex J. Kondonassis, David Ross Boyd and Regents Professor Emeritus, Professor Emeritus of Economics, University of Oklahoma. Received Ph.D. from Indiana University. Has published 80 articles, monographs, chapters and books primarily on global economic development and economic integration. He has directed 60 doctoral dissertations. 


\section{REFERENCES}

1. Boeke, J.H. 1953. Economics and Economic Policy of Dual Societies, New York: Harper and Row.

2. Bowman, M.J. 1966. "The Human Investment Revolution in Economic Thought" Sociology of Education, 39.

3. Hagen, Evertt. 1962. The Theory of Social Change: How Economic Growth Begins. Homewood, Illinois: Dorsey Press.

4. Higgins, Benjamin. 1968. Economic Development. New York: W.W. Norton.

5. Kuznets, Simon. 1955. "Toward or Theory of Economic Growth" in Robert Lekachman ed. National Policy for Economic Welfare at Home and Abroad, Garden City, New York: Double Day.

6. $\quad$ Lewis, Arthur. 1966. Development Planning. New York: Harper and Row.

7. McClelland, David. 1961. The Achieving Society. Princeton, New Jersey: D. Van Nostrand.

8. Meier, Gerald. 1976. Leading Issues in Economic Development. New York: Oxford University Press.

9. Mincer, Jacob. 1958. "Investment in Capital and Personal Income Distribution" in Journal of Political Economy, 66.

10. Nafziger, E. Wayne. 2006. Economic Development. New York: Cambridge University Press.

11. Psacharopoulos, G. and Woodhall, M. 1985. Education for Development: An Analysis of Investment Choice, New York: OUP.

12. Rostow, W.W. 1961. The Stages of Economic Growth: A Non- Communist Manifesto. Cambridge, Mass: CUP

13. Schultz, T.W. 1961. "Investment in Human Capital", A.E.A. 1951. Pg1-7.

14. Schumpeter, Joseph. 1961. The Theory of Economic Development. Cambridge, Massachusetts: Harvard University Press.

15. Timbergen, J. 1967. Development Planning. New York: McGraw-Hill.

16. Todaro, Michael and Smith, Stephen. 2006. Economic Development. New York: Pearson Addison Wesley.

17. Weber, Max. 1930. The Protestant Ethic and The Rise of Capitalism. New York. 
NOTES 